\title{
Global Higher Education: Examining Response to the COVID-19 Pandemic Using Agility and Adaptability
}

\author{
Thomas J. McCormack ${ }^{1}$, Pamela A. Lemoine ${ }^{2}$, Robert E. Waller ${ }^{1} \&$ Michael D. Richardson ${ }^{3}$ \\ ${ }^{1}$ Columbus State University, Columbus, Georgia, USA \\ ${ }^{2}$ Troy University, Troy, Alabama, USA \\ ${ }^{3}$ Global Tertiary Institute, Global Educational Consultant, USA \\ Correspondence: Michael D. Richardson, Global Tertiary Institute, Global Educational Consultant, Livingston, \\ TN 38570 , USA.
}

Received: December 1, 2020

Accepted: December 30, $2020 \quad$ Online Published: January 13, 2021

doi:10.20849/jed.v5i1.848

URL: https://doi.org/10.20849/jed.v5i1.848

\begin{abstract}
Global higher education institutions are significantly impacted by a key component of chaos during challenging times: the ability to effectively respond to ambiguity and uncertainty. Today's COVID-19 global pandemic created a challenge so quickly that higher education leaders had little opportunity to assess, evaluate and make informed judgments. The dynamics of the situation presented more complexities than ever previously faced. Global higher education institutions with the ability to manage ambiguity and uncertainty can successfully survive. Conversely, the inability to cope with change could lead to failure.
\end{abstract}

Keywords: global higher education, ambiguity, uncertainty, leadership, change, agility

\section{Introduction}

Global higher education institutions are now confronting a very complex world driven by the COVID-19 pandemic. Additionally, global higher education is facing two significant impediments to sustainability and survival. First, governments around the world have steadily minimized their support for public higher education,while expenditures have increased constantly. Second, governments are increasing pressure on universities to demonstrate the value of their degrees in short-term, quantitative and market-related measures (Antoine \& Van Langenhove, 2019). In this turbulent time when medical, social, and technology challenges require innovative solutions and new concepts, global higher education institutions must deliver both creativity for sustainability and resilience for accountability (Lemoine \& Richardson, 2019).

COVID-19 caused the closure of university campuses around the world and migration of all learning and teaching into digital environments. How did global universities immediately and effectively embrace the mass adoption of online learning (Mondol \& Mohiuddin, 2020)? Although technology-enhanced learning was used to some extent at most universities, the COVID-19 pandemic required expansion of existing infrastructure and more demanding forms of online learning (Naciri, Baba, Achbani, \& Kharbach, 2020). The abruptness of the shift meant that there were no opportunities to provide additional preparation for faculty or students before the switch to online teaching and learning. Did COVID-19 force online learning as a stop gap measure or the next solution for learning in global higher education (Neuwirth, Jović, \& Mukherji, 2020)?

The COVID-19 pandemic forced almost all global higher education institutions to rapidly move from on-campus instruction to online instruction whether the institution, the faculty or the students were ready for the move (Houlden \& Veletsianos, 2020). After the Chinese closed their institutions and moved to online learning the response became almost universal as institutions in all countries followed their example (Bao, 2020). The rapid expansion of online learning forced universities around the world to struggle with developing new policies, identifying new goals and directions, and implementing change processes to meet the needs of students in an online environment during this pandemic; however, the move to online did not come without risk (Williamson, Eynon, \& Potter, 2020). The pandemic has renewed attention to the importance of, and how little is known about, learning under stress and urgency in the middle of a crisis (Karalis, 2020).

Online learning further places emphasis on interactions between and among different channels to let learners be more engaged in the learning process (Riggs, 2020). What is currently being done with online learning is 
considered by many in the higher education community as a temporary solution to an immediate problem that will revert to face-to-face instruction after the pandemic (Golden, 2020). For instance, in the United States alone, about 2.3 million undergraduates, which is equivalent to $14 \%$ of the total undergraduate students in the US, studied entirely online in the fall of 2018, according to NCES (2019). Although institutions that normally teach face-to-face on campus will likely return to that mode of instruction, the special arrangements they put in place during the COVID-19 crisis may leave a lasting trace (Dhawan, 2020). The expansion of online learning in higher education will likely accelerate, and institutions will pursue the aspects of technology-based learning that they have found most useful (Vlachopoulos, 2020).

\section{Leading in Ambiguity and Uncertainty}

Continuous turbulence fueled by the COVID-19 pandemic has led global higher education institutions in a frantic search for means to maintain competitive advantages and relevance in this challenging environment (Robson \& Wihlborg, 2019). The phenomenon of COVID-19 has been characterized by abrupt changes and turbulence, forcing global higher education centers of learning to scramble to develop survival strategies (Melnyk, Pypenko, \& Maslov, 2020). Agility is a strategy that when implemented effectively promises institutions not only survival but a way to thrive in a fast-changing situation. Organizational agility is the competitive feature that is needed by institutions to survive turbulent environments by providing the possibility to swiftly and aptly respond (Mukerjee, 2014). One of the primary components of agility is the ability of institutions to respond to uncertainty; such is the case during COVID-19. To acquire organizational agility, the institution must be capable of dealing with unexpected changes and turbulence (Worley \& Jules, 2020).

Ambiguity is the vagueness of reality, mixed meaning, and/or cause and effect confusion while uncertainty is the lack of predictability and possibilities for surprise and/or shock (Waller, Lemoine, Garretson, \& Richardson, 2020b). Such is the world of COVID-19 experienced by global higher education leaders. Ambiguity and uncertainty often cause crises, setbacks, struggles, and obstacles which leaders see as adversity--a threat rather than an opportunity. This can prevent leaders from adapting to adversity and consequently, they are unable to maintain a stable and balanced leadership platform (Kouzes \& Posner, 2019). Adversity requires leaders to have extraordinary courage, showing resilience and skill with determination. However, leaders need to be open and transparent about what is going on and how the situation impacts the institution and members of the institution (Stewart, Khare, \& Schatz, 2016). To defeat adversity leaders, need to develop the ability to evaluate a situation, develop an action plan that addresses the right issues and exhibit the willingness to commit to their goals (Fernandez \& Shaw, 2020).

Planning and preparing for the unexpected and unknown while dealing with ambiguity and uncertainty are inherent parts of the leadership dynamics in complex organizations (Woods, 2020). Leading a global higher education institution is a complex and daunting challenge in the best of times but the global pandemic created an increasingly unstable and rapidly changing world (Marshall, Roache, \& Moody-Marshall, 2020). To survive, global higher education leaders need to understand that ambiguity and uncertainty produce setbacks, stress, and crises, yet may also produce valuable opportunities (Yan, 2020). Further, in this environment global higher education institutions are turbulent and volatile (Bruckmann, \& Carvalho, 2018). Turbulence is characterized by complexity as well as rapidity of change in the institution because turbulence accelerates the rate and complexity of interactive effects on the organization (Sae-Lim, 2019). This implies that skills to predict and control outcomes are obsolete and need to be replaced by the ability to recognize patterns and adapt quickly (Ulrich \& Yeung, 2019).

Effective leadership during times of crisis requires a dual focus on responding to immediate needs while also making strategic decisions that serve the long-term interests of the institution (Vecchiato, 2015). Higher education is not typically recognized for agility and speed, yet the immediate, and what some have characterized as heroic, response by global higher education institutions is most impressive; in reality there were really very few choices. Meanwhile, institutions of global higher education are working to redefine themselves during a time when the only certainty is uncertainty (Waller, Lemoine, Mense, \& Richardson, 2019).

Given the likelihood of continued COVID-19 complications, global higher education will likely operate in a continually fluid and uncertain environment characterized by ambiguity and uncertainty in addition to turbulence (Gilson \& Davis, 2019). Higher education leaders are caught in a quandary. The rapid infusion of technology has created increased demands that drive this new world. Technology has a long and interesting history in higher education, but never have the requirements for implementation and utilization been so great (Lemoine, Waller, Garretson, \& Richardson, 2020b). 


\section{The Need for Agility and Adaptability}

Global higher education institutions are beginning to embrace agility as a means to cope with complexity, uncertainty and fast changes in the global marketplace. Therefore, one of the skills that global higher education institutions need in the turbulent environment of COVID-19 is agility (Menon \& Suresh, 2020). Agility provides the institution with the possibility of quick response and allows the institution to improve its efficiency. Agile, by the face meaning of this word, is the ability to create and respond to change (Holbeche, 2018). It is a way of dealing with, and ultimately succeeding in, an uncertain and turbulent environment. Three core imperatives are essential for global higher education institutions during ambiguity and uncertainty: responding to student needs, agility, and the ability to change (Lemoine, Waller, Garretson, \& Richardson, 2020a).

Agility is the ability to respond to unpredictable change by reacting quickly and effectively to changing environments. Agility is the capability to make timely, effective, and sustained changes. Agility necessitates speed and flexibility as the primary attributes of an agile institution. Agility is often described as proactive responses to change (Moon, 2020).

As a result, agility implies the ability of the institution to survive with flexibility in an unpredictable environment. The agility concept encompasses both flexibility and adaptability (Prejean, Kilcoyne, Liao, \& Parker, 2019). The commitment to agility goes far beyond proposing new policies and procedure; it requires leaders to rethink organizational structures, functions and conventional management methods such as planning and measurement systems which are rooted in the status quo (Teece, Peteraf, \& Leih, 2016).

COVID-19 was a test of organizational agility (Wu \& Lin, 2020), with many initially focused on transitioning content to an online environment, and not necessarily on online pedagogy (Blumenstyk, 2020). Organizational agility, or the ability to continuously adjust and adapt strategically, is increasingly considered a vital higher education success factor. The ability to change continuously and effectively is key to survival and future prosperity (Stefan \& Nazarov, 2020). The ability of the institution to use agility to respond to COVID-19 will likely cause many university presidents to lose their job and others to be labeled heroes due to their ability to have their institution, particularly faculty, able to respond to COVID-19 with agility and purpose (Rey, Pitta, Ramonas, \& Sotok, 2019). Agility is said to be an organization-wide capability meant to handle situations arising in an unanticipated fashion in the environment through rapid response. Was there resistance from some faculty? Obviously. However, they accepted the challenge and persevered largely in response to the needs of their students (Rapanta, Botturi, Goodyear, Guàrdia, \& Koole, 2020). Adaptable behavior emphasizes professional flexibility, which includes accepting many responsibilities and changing roles easily in different tasks or teams.

Doerfel and Prezelj (2017) assert another dimension of the workforce agility behaviors includes resilience. Resilience manifests in positive attitudes to novel ideas, technologies and other adjustments such as process changes and tolerance of unpredicted situations, differing opinions and coping with stressful situations, just as found in response to COVID-19 by going totally online in a few days, not a few years (Watermeyer, Crick, Knight, \& Goodall, 2020).

One capability that higher education institutions need in today's turbulent environment is adaptability (Sutin, 2016). Adaptability underlies the fit of organizational operations to their environment while flexibility emphasizes the readiness of organizational resources and the ease of resource mobilization. The institution must adapt to unpredictable changes quickly and efficiently. The issue is whether adaptation is aligned with the changes necessary in the environment (Ansell, 2017).

COVID-19 has caused the closure of university campuses around the world and migration of all learning and teaching into digital environments. How did global universities immediately and effectively embrace the mass adoption of online learning? Although technology-enhanced learning was used to some extent at most universities, the COVID-19 pandemic required expansion of existing infrastructure and more demanding forms of technology-enhanced learning (Zimmerman, 2020). The abruptness of the shift meant that there were no opportunities to provide additional preparation for faculty before the transference to online teaching and learning. Did COVID-19 force online learning as a stop gap measure or the next solution for learning in global higher education (Rahim, Burrell, \& Duncan, 2020)?

Adapt or get left behind. Global higher education institutions with the ability to adapt to the changes in their respective ecosystems will successfully survive. Conversely, the inability to cope with the changes will lead to failure (Kawamorita, Salamzadeh, Demiryurek, \& Ghajarzadeh, 2020). Global higher education institutions that are transformative organizations continually adapt, adopt, and renew, as and when required due to the need to adapt or perish in the face of unprecedented change. The global higher education environment demands continual changes (Izumi, Sukhwani, Surian, \& Shaw, 2020). Thus, it is imperative for global higher education 
institutions to adapt to the changes that pose threats to them so that they can survive because the institution may not succeed without making appropriate changes, particularly in light of the changes initiated as a result of COVID-19 (Evans, 2020).

\section{Recommendations}

1. Universities undergoing a rapid change period need to be conscious of their ability to continuously monitor the quality of the learning design.

2. Global higher education institutions must pivot from crisis management to long-range planning.

\section{Conclusions}

1. Change is a continuous process of adaptation that aligns institutional competence with the environment.

2. COVID-19 has made it evident that everything cannot be formalized into predictable, mechanistic patterns that are easy to understand.

3. Adaptive challenges like COVID-19 do not have easy solutions.

4. The intensity of COVID-19 compels change that is exceptional and innovative.

5. What is problematic is to expect a clear answer to a complex challenge when the real and immediate task is to figure out what the issues are and develop a strategy on how to respond.

6. The key to leadership is to understand a problem from different perspectives and plan accordingly when there are no predictable answers or outcomes.

7. The COVID-19 pandemic accelerated the volatility, uncertainty, complexity and ambiguity (VUCA) across global higher education and technological ecosystems.

\section{References}

Ansell, C. (2017). Turbulence, adaptation, and change. In C. K. Ansell, J. Trondal, \& M. Ogard (Eds.), Governance in turbulent times (pp. 77-104). London, UK: Oxford University Press. https://doi.org/10.1093/acprof:oso/9780198739517.003.0004

Antoine, A., \& Van Langenhove, L. (2019). Global challenges and trends of university governance structures. In University governance and academic leadership in the EU and China (pp. 233-245). Hershey, PA: IGI Global. https://doi.org/10.4018/978-1-5225-7441-5.ch014

Bao, W. (2020). COVID-19 and online teaching in higher education: A case study of Peking University. Human Behavior and Emerging Technologies, 2(2), 113-115. https://doi.org/10.1002/hbe2.191

Blumenstyk, G. (2020, March). Why coronavirus looks like a 'black swan' moment for higher ed. Chronicle of Higher Education. Retrieved from https://www.chronicle.com/article/Why-Coronavirus-Looks-Like-a/248219?cid=cp275

Bruckmann, S., \& Carvalho, T. (2018). Understanding change in higher education: An archetypal approach. Higher Education, 76(4), 629-647. https://doi.org/10.1007/s10734-018-0229-2

Dhawan, S. (2020). Online learning: A panacea in the time of COVID-19 crisis. Journal of Educational Technology Systems, 49(1), 5-22. https://doi.org/10.1177/0047239520934018

Doerfel, M. L., \& Prezelj, I. (2017). Resilience in a complex and unpredictable world. Journal of Contingencies and Crisis Management, 25(3), 118-122. https://doi.org/10.1111/1468-5973.12177

Evans, M. (2020). COVID-19 exposes sector's vulnerability. Advocate: Journal of the National Tertiary Education Union, 7(1), 4-5.

Fernandez, A. A., \& Shaw, G. P. (2020). Academic leadership in a time of crisis: The coronavirus and COVID-19. Journal of Leadership Studies, 14(1), 39-45. https://doi.org/10.1002/jls.21684

Gilson, L. L., \& Davis, W. D. (2019). Managing in an age of complexity and uncertainty. Group \& Organization Management, 44(2), 243-246. https://doi.org/10.1177/1059601119836545

Golden, C. (2020, March). Remote teaching: The glass half-full. Educause Review. Retrieved from https://er.educause.edu/blogs/2020/3/remote-teaching-the-glass-half-full

Holbeche, L. S. (2018). Organisational effectiveness and agility. Journal of Organizational Effectiveness: People and Performance, 5(4), 302-313. https://doi.org/10.1108/JOEPP-07-2018-0044

Houlden, S., \& Veletsianos, G. (2020). Coronavirus pushes universities to switch to online classes--But are they 
ready?. The Conversation. Retrieved from https://theconversation.com/coronaviruspushes-universities-to-switch-to-online-classes-but-arethey-ready-132728

Izumi, T., Sukhwani, V., Surjan, A., \& Shaw, R. (2020). Managing and responding to pandemics in higher educational institutions: Initial learning from COVID-19. International Journal of Disaster Resilience in the Built Environment. https://doi.org/10.1108/IJDRBE-06-2020-0054

Karalis, T. (2020). Planning and evaluation during educational disruption: Lessons learned from COVID-19 pandemic for treatment of emergencies in education. European Journal of Education Studies, 7(4), $125-142$.

Kawamorita, H., Salamzadeh, A., Demiryurek, K., \& Ghajarzadeh, M. (2020). Entrepreneurial universities in times of crisis: Case of COVID-19 pandemic. Journal of Entrepreneurship, Business and Economics, 8(1), 77-88. https://doi.org/10.1080/08276331.2020.1821158

Kouzes, J., \& Posner, B. (2019). Leadership in higher education: Practices that make a difference. San Francisco, CA: Berrett-Koehler Publishers.

Lemoine, P. A., \& Richardson, M. D. (2019). Creative disruption in higher education: Society, technology, and globalization. In Educational and social dimensions of digital transformation in organizations (pp. 275-293). Hershey, PA: IGI Global. https://doi.org/10.4018/978-1-5225-6261-0.ch011

Lemoine, P. A., Waller, R. E., Garretson, C. J., \& Richardson, M. D. (2020a). Analyzing uncertainty and change in the advancement of global higher education. International Journal of Education Humanities and Social Sciences, 3(4), 208-223.

Lemoine, P. A., Waller, R. E., Garretson, C. J., \& Richardson, M. D. (2020b). Examining technology for teaching and learning. Journal of Education and Development, 4(2), 80-89. https://doi.org/10.20849/jed.v4i2.781

Marshall, J., Roache, D., \& Moody-Marshall, R. (2020). Crisis leadership: A critical examination of educational leadership in higher education in the midst of the COVID-19 pandemic. International Studies in Educational Administration (CCEAM)), 48(3).

Melnyk, Y. B., Pypenko, I. S., \& Maslov, Y. V. (2020). COVID-19 pandemic as a factor revolutionizing the industry of higher education. Rupkatha Journal on Interdisciplinary Studies in Humanities, 12(5), 1-6. https://doi.org/10.21659/rupkatha.v12n5.rioc1s19n2

Menon, S., \& Suresh, M. (2020). Factors influencing organizational agility in higher education. Benchmarking: An International Journal. https://doi.org/10.1108/BIJ-04-2020-0151

Mondol, M. S., \& Mohiuddin, M. G. (2020). Confronting COVID-19 with a paradigm shift in teaching and learning: A study on online classes. International Journal of Social, Political and Economic Research, 7(2), 231-247. https://doi.org/10.46291/IJOSPERvol7iss2pp231-247

Moon, M. J. (2020). Fighting against COVID-19 with agility, transparency, and participation: Wicked policy problems and new governance challenges. Public Administration Review, 80(4), 651-656. https://doi.org/10.1111/puar.13214

Mukerjee, S. (2014). Agility: A crucial capability for universities in times of disruptive change and innovation. Australian Universities' Review, 56(1), 56.

Naciri, A., Baba, M. A., Achbani, A., \& Kharbach, A. (2020). Mobile learning in higher education: Unavoidable alternative during COVID-19. Aquademia, 4(1), ep20016. https://doi.org/10.29333/aquademia/8227

National Center for Education Statistics. (2019). Digest of education statistics 2019. Washington, DC: United States Department of Education.

Neuwirth, L. S., Jović, S., \& Mukherji, B. R. (2020). Reimagining higher education during and post-COVID-19: Challenges and opportunities. Journal of Adult and Continuing Education. https://doi.org/10.1177/1477971420947738

Prejean, E. A., Kilcoyne, M. S., Liao, W., \& Parker, C. (2019). Is higher education talking and walking agile management: A review of the literature. American International Journal of Business Management, 2(7), $8-18$.

Rahim, E., Burrell, D. N., \& Duncan, T. (2020). Best practices and emerging trends for knowledge-based organizations and academic institutions around e-learning. International Journal of Smart Education and Urban Society (IJSEUS), 11(2), 16-27. https://doi.org/10.4018/IJSEUS.2020040102

Rapanta, C., Botturi, L., Goodyear, P., Guàrdia, L., \& Koole, M. (2020). Online university teaching during and 
after the Covid-19 crisis: Refocusing teacher presence and learning activity. Postdigital Science and Education. https://doi.org/10.1007/s42438-020-00155-y

Rey, C., Pitta, N., Ramonas, D., \& Sotok, P. (2019). Agile purpose: Overcoming bureaucracy. In Purpose-driven organizations. Cham, Switzerland: Palgrave Macmillan. https://doi.org/10.1007/978-3-030-17674-7

Riggs, S. (2020, April). Student-centered remote teaching: Lessons learned from online education. Educause Review.

Retrieved

from

https://er.educause.edu/blogs/2020/4/student-centered-remoteteaching-lessons-learned-from-online-education

Robson, S., \& Wihlborg, M. (2019). Internationalisation of higher education: Impacts, challenges and future possibilities. European Education Research Journal, 18(2), 127-134. https://doi.org/10.1177/1474904119834779

Sae-Lim, P. (2019). Leadership competencies in turbulent environment. Journal of MCU Peace Studies, 7(6), 11552266.

Stefan, T., \& Nazarov, A. D. (2020, November). Challenges and competencies of leadership in Covid-19 Pandemic. In Research technologies of pandemic coronavirus impact (RTCOV 2020) (pp. 518-524). Amsterdam, The Netherlands: Atlantis Press. https://doi.org/10.2991/assehr.k.201105.092

Stewart, B., Khare, A., \& Schatz, R. (2016). Volatility, uncertainty, complexity and ambiguity in higher education. In Managing in a VUCA world (pp. 241-250). Cham, Switzerland: Springer. https://doi.org/10.1007/978-3-319-16889-0_16

Sutin, S. (2016). Reforming higher education from within: Lessons learned from other mature sectors of the economy. International Journal of Educational Development, 58, 18-25. https://doi.org/10.1016/j.ijedudev.2016.11.003

Teece, D., Peteraf, M., \& Leih, S. (2016). Dynamic capabilities and organizational agility: Risk, uncertainty, and strategy in the innovation economy. California Management Review, 58(4), 13-35. https://doi.org/10.1525/cmr.2016.58.4.13

Ulrich, D., \& Yeung, A. (2019). Agility: The new response to dynamic change. Strategic HR Review, 18(4), 161-167. https://doi.org/10.1108/SHR-04-2019-0032

Vecchiato, R. (2015). Strategic planning and organizational flexibility in turbulent environments. Foresight, 17(3), 257-273. https://doi.org/10.1108/FS-05-2014-0032

Vlachopoulos, D. (2020). COVID-19: Threat or opportunity for online education?. Higher Learning Research Communications, 10(1), 2. https://doi.org/10.18870/hlrc.v10i1.1179

Waller, R. E., Lemoine, P. A., Garretson, C. J., \& Richardson, M. D. (2020b). Global higher education: Complexity and uncertainty. International Education and Research Journal, 6(4), 57-58.

Waller, R. E., Lemoine, P. A., Mense, E. G., \& Richardson, M. D. (2019). Higher education in search of competitive advantage: Globalization, technology and e-learning. International Journal of Advanced Research and Publications, 3(8), 184-190. https://doi.org/10.20849/jed.v3i2.613

Watermeyer, R., Crick, T., Knight, C., \& Goodall, J. (2020). COVID-19 and digital disruption in UK universities: afflictions and affordances of emergency online migration. Higher Education, 1-19. https://doi.org/10.1007/s10734-020-00561-y

Williamson, B., Eynon, R., \& Potter, J. (2020). Pandemic politics, pedagogies and practices: Digital technologies and distance education during the coronavirus emergency. Learning, Media and Technology, 45(2), 107-114. https://doi.org/10.1080/17439884.2020.1761641

Woods, D. D. (2020). The strategic agility gap: How organizations are slow and stale to adapt in turbulent worlds. In Human and Organisational Factors (pp. 95-104). Cham, Switzerland: Springer. https://doi.org/10.1007/978-3-030-25639-5_11

Worley, C. G., \& Jules, C. (2020). COVID-19's uncomfortable revelations about agile and sustainable organizations in a VUCA world. The Journal of Applied Behavioral Science, 56(3), 279-283. https://doi.org/10.1177/0021886320936263

Wu, S., \& Lin, M. (2020). Analyzing the Chinese budgetary responses to COVID-19: Balancing prevention and control with socioeconomic recovery. Journal of Public Budgeting, Accounting \& Financial Management, 32(5), 929-937. https://doi.org/10.1108/JPBAFM-08-2020-0142 
Yan, Z. (2020). Unprecedented pandemic, unprecedented shift, and unprecedented opportunity. Human Behavior and Emerging Technologies, 2, 110-112. https://doi.org/10.1002/hbe2.192

Zimmerman, J. (2020, March). Coronavirus and the great online-learning experiment. Chronicle of Higher Education. Retrieved from https://www.chronicle.com/article/Coronavirusthe-Great/248216

\section{Copyrights}

Copyright for this article is retained by the author(s), with first publication rights granted to the journal.

This is an open-access article distributed under the terms and conditions of the Creative Commons Attribution license (http://creativecommons.org/licenses/by/4.0/). 